\title{
THE REPRODUCTIVE PERFORMANCE OF EGYPTIAN COWS AND BUFFALOES IN MIXED CROP-LIVESTOCK SYSTEM IN SMALL HOLDINGS IN FAYOUM REGION.
}

\author{
Ali Rabie Abd El- Rahman \\ Department of Animal Production, Faculty of Agriculture, Fayoum University, Egypt.
}

\section{ABSTRACT:}

A field survey was conducted in many villages in Fayoum Governorate in 30 small holdings, with $<10$ animal each. About $70 \%$ of total animal production is produced from the small holdings in Egypt. A monthly monitoring program was carried out along four successive years to determine productive and reproductive performance of buffaloes, Baladi cows and crossbreed cows under mixed farming system (plant and animal production) of small holdings as well as the reproductive management system for animals of the small holdings. Baladi cows represented the highest percentage of the herd structure $(54 \%)$ followed by buffaloes $(38 \%)$, while percentage of crossbreed cows amounted (8\%). On the other side, the breedable females percentages in Baladi cows, buffaloes and crossbreed cows were 28,19 and $4 \%$ respectively. In addition, the young females $(<1.5$ year age) were 17, 11 and $2 \%$ in Baladi cows, buffaloes and cross breed cows respectively. On the other hand the percentages of young Baladi , buffaloes and crossbreed males were 15, 7 and $1 \%$ respectively .Generally, the farmers fed their animals on mainly berseam during winter - spring, and fed on crop residues, concentrates and variable amounts of green fodder (mostly - Darawah) during summer- autumn. Sold cows and buffaloes' calves were weaned at 1.5 and 3 months old, respectively. Those retained for breeding were weaned at 3 and 4 months of age respectively. Most farmers (90\%) used frequent bellowing as a sign for detecting estrus in buffaloes, while mounting activity was the most used sign (92\%)in cattle. Age at first calving in Baladi cows, crossbreed cows and buffaloes averaged $32.42 \pm 1.52$, $33.4 \pm 1.4$ and $34.86 \pm 1.86$ months respectively. The intervals from calving to first post - partum estrus, first post - partum service, fertile service and calving interval for Baladi cows were 73.46 $\pm 2.94,73.92 \pm$ $2.52,101.06 \pm 3.08$ and $386.94 \pm 13.2$ days, respectively. While the same estimates were $80.44 \pm 3.2,83.12 \pm 2.82,105.4 \pm 3.1$ and $396.76 \pm 13.50$ days for crossbreed cows. and $92.58 \pm 4.68,91.50 \pm 3.46,119.94 \pm 3.32$ and $444.58 \pm 14.74$ days for buffaloes respectively. Number of services required for conception averaged 1.5 in Baladi and 1.58 in crossbreed cows compared to 1.68 for buffaloes.

Key words: Baladi cows, cross-bred cows, buffaloes, small holdings, management system, reproductive and, productive performance.

\section{INTRODUCTION}

Cattle and buffaloes are the most prominent large ruminants in Egyption small holding farms, About $90 \%$ of Baladi and cross-bred cows and buffaloes are raised in this small holdings (Nigm, 1996 and El-Wardani, et al., 2000). From the productive view, the performance of Baladi cows and buffaloes were influenced to a large extent by its reproductive performance which is, in turn, affected by many environmental conditions and management practices. Most of the scientific knowledge were contributed mainly to the research on native

Fayoum J. Agric. Res. \& Dev., Vol. 21, No.1, January, 2007 
cattle and buffaloes production belonging to the large experimental or stateowned herds. On the other hand, very few reports are available for Baladi cows and buffaloes productivity and managerial practices under the prevailing conditions of small holdings (Aboul-Ela, 1993; Sadek, et al., 1994; AboulEla, et al., 2000; El-Wardani et al., 2000). This manner lead to incomplete performance of native cattle as well as buffaloes in Egypt High reproductive efficiency is one of the major criteria for achieving a higher economic benefit and maximizing the farm gross margin. Thus the reproductive traits such as age at first calving, number of services per conception, conception rate, postpartum estrus interval, post-partum service interval, days open, service period and calving interval could be used to full of the gab in this knowledge as a main parameter used to assess reproductive performance. In the same time, a lot of information which influence sequence of parity, animal body score and on previous parameters should be also considered. On the other hand, the signs used for estrous detection in cattle and buffaloes differ especially between animals kept under small holders conditions and seem to be distinctly different from these known for standard cattle breeds. Aboul-Ela, et. al. (2000). This survey study aims to point out the main features of the production system and management practices of Baladi cows, cross breed cows and buffaloes raised under the traditional conditions of small holdings.

\section{MATERIALS AND METHODS:}

The present study was carried out in the North Estern of Senores and Tamih zone of Fayoum Governorate, Egypt. The main feature of this area is intensive breeding of cattle and buffaloes. Total of 30 small holdings of cattle and buffaloes were included in the present survey study, which lasted four years. Out of the 30 farms, ten have an average herd size of less than 8 breedable females (cows or buffaloes). Farmers were identified as ordinary farmers who own and operate mixed farming system, where animal raising and crop cultivation activities are practiced

Animal were kept under the traditional system of feeding and management adopted by the Egyption farmers. Animals were fed mainly on forages and crop residues produced on the farm. Thus, in winter and spring fed mainly on (berseem) clover as well as variable quantities of concentrate mixture and wheat or rice straw. In summer and autumn fed wheat or rice straw, concentrate mixture and variable amounts of green fodder (mostly darawah). Suckling period was 1.5 and 3 months in buffaloes and cattle sold calves, while those retained for breeding were weaned at 3.0 and 4.0 months respectively. The symptom of estrous detection in either buffaloes or cows, the symptoms were recorded by most of the farmers as bellowing, mounting each other, response to vulva message, low appetite, response to putting hand on rump, tail raising, high body temperature and drop in milk production. Breedable females were serviced by the available bull in the village, with the exception of few cases that were artificially inseminated. The traditional housing systems are enclosures (stables) of various types, (closed or semiopen attached to their houses during the night, while in the daylight, animals were housed in open sheds nearby the houses or in the field). Breedable cows and buffaloes were divided into 5 classes as body condition score $(1=$ very thin, $2=$ thin, $3=$ moderate, $4=$ fat and $5=$ very fat) to the nearest quarter point according to Corro et al., (1999). Breedable animals were divided as

Fayoum J. Agric. Res. \& Dev., Vol. 21, No.1, January, 2007 
THE REPRODUCTIVE PERFORMANCE OF EGYPTIAN COWS AND... OV sequence of parity to seven groups. Data included information details about reproduction were collected as, age at first calving (AFC), number of days from calving to first estrous (post - partum estrous interval, PPEI), first service (post- partum service interval, PPSI), fertile service (days open, DO) as well as interval from the first post-partum service to fertile service (service period, SP), number of service per conception (NSC), gestation period (GP) and calving interval $(\mathrm{CI})$.

Number of animals or observations of different parameters differed due to continuous herd movement (selling \& purchase) in different farms. the data collected were statistically analyzed using (SPSS, 1997).

\section{RESULTS AND DISCUSSION:}

Table 1 showed that, under the traditional management systems, three types of dairy animal, were differentiated in the monitored farms, Baladi and cross bred cows and buffaloes. The ratio between Baladi cows and buffaloes was 1.4: 1.0 this agrees with the report of Fayoum Governorate description with Information (CID 2005). While in the case of breeding animals the ratio was 1.47: 1.00, also the same trend was noticed in young heifers and males, in the same time the cross breed cows presented a less percentage in the herd structure of the small holdings. The Baladi cows represented $54 \%$ of the herd structure followed by buffaloes $(38 \%)$ and cross breed cows $8 \%$. The corresponding percentages for young heifers from total monitoring animals were 17,11 and $2 \%$, respectively which were 10,8 and $1 \%$ for males. Dissimilar herd structure was obtained by El-Wardani et al. (2000). This indicates that Baladi cows are common animals in Upper Egypt as compared with delta region where buffaloes are common animals. The farmers in Upper Egypt prefer Baladi cows as beef producing animals, while in delta region the farmers prefer buffaloes as milk producing animals. However, the ratio between breeding animals to young animals was still similar in both cattle and buffaloes, this could be due to farmers usually selling their calves at an earlier age, without changing the herd size. Throughout the monitoring period, it was noticed from data in Table 2 . That only 30,18 and $37.5 \%$ of breeding animals were born on the same farm and the remaining were purchased from markets for Baladi cows, buffaloes and cross breed cows, respectively. However, in the case of young animals a nearly reverse trend was observed.

Table 1: Herd structure percentages of examined small holdings

\begin{tabular}{|l|c|c|c|c|c|c|c|c|}
\hline \multirow{2}{*}{ Item } & \multicolumn{2}{|c|}{$\begin{array}{c}\text { Breeding } \\
\text { animal }\end{array}$} & \multicolumn{2}{c|}{$\begin{array}{c}\text { Young } \\
\text { heifers }\end{array}$} & \multicolumn{2}{c|}{$\begin{array}{c}\text { Young } \\
\text { Male }\end{array}$} & \multicolumn{2}{c|}{ Total } \\
\cline { 2 - 10 } & No & $\%$ & No & $\%$ & No & $\%$ & No & $\%$ \\
\hline Baladi cows & 50 & 28 & 30 & 17 & 18 & 10 & 98 & 54 \\
\hline Buffaloes & 34 & 19 & 20 & 11 & 14 & 8 & 68 & 38 \\
\hline Cross breeding cows & 8 & 4 & 4 & 2 & 2 & 1 & 14 & 8 \\
\hline & & & & & & & 180 & 100 \\
\hline
\end{tabular}

It is of interest to compare the herd structure percentages of their populations in small farms in Table 3 . Farmers were towards raising male calves of cattle and buffaloes. Male of Baladi cattle constituted about $18 \%$ of the total Baladi cattle population distributed between $10 \%$ of young $(<1.5$ year) and $8 \%$ of older ( $>1.5$ year) of age. The comparable values of buffaloes $(21 \%)$ were $9 \%$ of $<1.5$ year and $12 \%$ of 71.5 year. This indicated that in the small farms in Fayoum region male calves of Baladi cattle and buffaloes are

Fayoum J. Agric. Res. \& Dev., Vol. 21, No.1, January, 2007 
mainly used for fattening. The contrary was found by Aboul-Ela et al., (2000), in Delta region, that male cattle calves were used for fattening while male buffaloes calves are sold at younger age as veal calves.

Table 2 : Herd structure as stratified according to source of animals.

\begin{tabular}{|l|c|c|c|c|c|c|}
\hline \multirow{2}{*}{ Source of animal } & \multicolumn{2}{|c|}{ Baladi cows } & \multicolumn{2}{c|}{ Buffaloes } & \multicolumn{2}{c|}{ Cross breed ows } \\
\cline { 2 - 7 } & No & $\%$ & No & $\%$ & No & $\%$ \\
\hline Own farm breeding animals* & 15 & 30 & 6 & 18 & 3 & 37.5 \\
\hline Off-farm breeding animals** & 35 & 70 & 28 & 82 & 5 & 62.5 \\
\hline Own farm young animals* & 17 & 57 & 12 & 60 & 2 & 50 \\
\hline Off farm young animals** & 13 & 43 & 8 & 40 & 2 & 50 \\
\hline
\end{tabular}

* Animals were born and reared on the farm .

** Animal were purchased from the market or other farms

Table 3 : herd structure percentages of their populations .

\begin{tabular}{|c|c|c|c|c|c|c|c|c|c|c|}
\hline & \multicolumn{2}{|c|}{$\begin{array}{l}\text { Breeding } \\
\text { females }\end{array}$} & \multicolumn{4}{|c|}{ Heifers } & \multicolumn{4}{|c|}{ Male } \\
\hline & \multirow[b]{2}{*}{ No } & \multirow[b]{2}{*}{$\%$} & \multicolumn{2}{|c|}{$<1.5$ year } & \multicolumn{2}{|c|}{$>1.5$ year } & \multicolumn{2}{|c|}{$<1.5$ year } & \multicolumn{2}{|c|}{$>1.5$ year } \\
\hline & & & No & $\%$ & No & $\%$ & No & $\%$ & No & $\%$ \\
\hline Baladi cows & 50 & 51 & 16 & 16 & 14 & 14 & 10 & 10 & 8 & 8 \\
\hline Buffaloes & 34 & 50 & 11 & 16 & 9 & 13 & 6 & 9 & 8 & 12 \\
\hline Cross breed cow & 8 & 57 & 2 & 14 & 2 & 14 & 1 & 7 & 1 & 7 \\
\hline
\end{tabular}

Nevertheless, the trend which has been found in Fayoum, for fattening buffalo calves can be utilized to the return of national ("Betillo)" project since the skills and experience for the development of national red meat production from endogenous livestock breeds in Egypt are available in Fayoum .

The averages of suckling periods in Baladi, cross breed cows and buffalo calves (Table 4) in winter and spring seasons were (115.7 \pm 8.3$),(113.5 \pm 6.3)$ and (93.4 \pm 6.2$)$ days, respectively. The differences among Baladi, cross breed and buffaloes calves were significant $(p<0.05)$. The same trend was observed in summer and autumn calving seasons, the values were $119.8 \pm 7.9,118.2 \pm 7.3$ and 112.2 \pm 7.1 days respectively, for breeding purpose It can be seen that the suckling period was affected significantly $(\mathrm{p}<0.05)$ in both Baladi and crossbreed as compared with buffaloe calves in different seasons. It could be noticed that the suckling period of buffaloe is shorter. This is due to the fact that some farmers sell their buffaloe calves at an early age to save the expensive milk.

Adoul-Ela et al. (2000) found that suckling period in small farms were 1.5 and 2.6 months for sold buffaloes and Baladi calves, while in the case of retained calves for breeding it were 3.0 and 3.7 months, respectively. El-Khashab et al. (1984) found that suckling period was $<40$ days for young calves that were slaughtered for veal meet, while this period was $>50$ days for young calves which were kept till weaning for breeding purpose.

Small farmers in the studied area practiced different crop rotations. However, it seems that maize, cotton and darawah are the dominant summerautumn crops (Table 5), while berseem and wheat are the main winter crops. Most small farms (91.2\%) planted berseem as a fodder crop for winter-spring, covering about $43 \%$ of the total planted area. In summer autumn, however, only $26.1 \%$ of farmers produced fodder crop covering about $14.97 \%$ of total

Fayoum J. Agric. Res. \& Dev., Vol. 21, No.1, January, 2007 
THE REPRODUCTIVE PERFORMANCE OF EGYPTIAN COWS AND... O planted area averaging 0.9 feddan. The dominance of wheat and maize as field crops indicates the availability of large quantities of their by-products (straw and residual maize plants) as feed resource for livestock.

Table 4: The average $\pm \mathrm{SE}$ of suckling period of examined groups per day in different calving seasons.

\begin{tabular}{|c|c|c|c|}
\hline Item & Buffaloe calves & Cross breed cows & Baladi cows \\
\hline \multicolumn{4}{|c|}{ Breeding purpose } \\
\hline Winter and spring & $93.4 \pm 6.2^{b}$ & $113.5 \pm 6.3^{\mathrm{a}}$ & $115.7 \pm 8.3^{\mathrm{a}}$ \\
\hline Summer and autumn & $112.2 \pm 7.1^{b}$ & $118.2 \pm 7.3^{\mathrm{a}}$ & $119.8 \pm 7.9^{a}$ \\
\hline \multicolumn{4}{|c|}{ Veal meat purpose } \\
\hline Winter and spring & $43.7 \pm 2.4^{b}$ & $85.4 \pm 5.2^{\mathrm{a}}$ & $88.7 \pm 11.2^{\mathrm{a}}$ \\
\hline Summer and autumn & $55.3 \pm 3.2^{b}$ & $101.5 \pm 6.4^{\mathrm{a}}$ & $104.2 \pm 9.6^{\mathrm{a}}$ \\
\hline
\end{tabular}

Average in the same row having different superscript a , b differ significantly $\mathrm{p}<0.05$.

Table 5: Distribution of the main planted crops in small holdings surveyed in winter and summer cropping seasons.

\begin{tabular}{|c|c|c|c|}
\hline Crop & $\begin{array}{c}\text { Percentage of } \\
\text { holdings planting } \\
\text { the crop }\end{array}$ & $\begin{array}{c}\text { Average planted } \\
\text { area (fedden ) / } \\
\text { holding }\end{array}$ & $\begin{array}{c}\text { Area of the crop as } \\
\text { percentage of total } \\
\text { planted area served }\end{array}$ \\
\hline \multicolumn{5}{|c|}{ 1- Summer Autumn season } \\
\hline Rice & 5.1 & $0.16 \pm 1.02$ & 2.76 \\
\hline Cotton & 41.5 & $1.94 \pm 0.17$ & 32.28 \\
\hline Maize & 46.2 & $1.91 \pm 0.15$ & 31.86 \\
\hline Darawah & 26.1 & $0.90 \pm 0.48$ & 14.97 \\
\hline Sweet sorghum & 5.4 & $0.83 \pm 0.27$ & 3.88 \\
\hline Vegetables & 5.1 & $0.21 \pm 1.2$ & 0.72 \\
\hline Melon (for seeds) & 3.2 & $0.04 \pm 0.98$ & 42.6 \\
\hline \multicolumn{5}{|c|}{$\mathbf{2 - ~ W i n t e r - ~ S p r i n g ~ s e a s o n ~}$} \\
\hline Berseem & 91.2 & $2.56 \pm 0.14$ & 51.0 \\
\hline Wheat & 71.5 & $3.06 \pm 0.16$ & 3.7 \\
\hline Beet & 4.2 & $0.22 \pm 1.1$ & 2.7 \\
\hline Vegetables & 5.5 & $0.16 \pm 1.05$ & \\
\hline
\end{tabular}

Feed resources and feeding system presented in Table 6 showed that, In winter - spring, most farmers (69.5) feed their animals solely on berseam clover, while the $22.5 \%$ of farmers provide their animals with crop residues and concentrates along with berseem. This is consistent with the cropping system, where almost all farmers plant berseam in abundant quantities about $43 \%$ of the total cultivated area .On the other hand, during summer-autumn a large proportion of the small holders surveyed (about 63\%) feed their cattle and buffaloes on crop residues, concentrates and variable quantities of green fodder, while about $29 \%$ of them only use crop residues and concentrates. This system of feeding indicates a severe shortage of green fodder over the summer season compared with large amounts of berseem produced during winter/ spring. Such findings is consistent with those reported by other investigators (Hathout et al., 1996; Aboul-Ela et al., 2000; Salem 2003) who indicated imbalance of feed resources for livestock in Egypt between different seasons of the year may have direct impact on livestock reproductive performance. With the tendency of large proportion of animal population to calve during autumn / winter (El-Wardani et al., 2000), the early post partum

Fayoum J. Agric. Res. \& Dev., Vol. 21, No.1, January, 2007 
period in these animal is likely to coincide within a period of feeding berseem clover only.

Table 6. Feed resource and feeding system for cattle and buffaloes at small holdings in summer - autumn and winter - spring seasons, as percentages of total number of holdings surveyed.

\begin{tabular}{|l|c|c|}
\hline \multicolumn{1}{|c|}{ Type of feeds } & Summer - Autumn & Winter - Spring \\
\hline Green feeds only & 5 & 69.5 \\
\hline Green feeds and concentrates & 4 & 6 \\
\hline $\begin{array}{l}\text { Crop residues, concentrates and green } \\
\text { feeds }\end{array}$ & 62.5 & 22.5 \\
\hline Crop residues and concentrates & 28.5 & 2 \\
\hline
\end{tabular}

Estrous detection expressed as percentage of different symptoms in Baladi, crossbreed cows and buffaloes are presented in Table 7. Most farmers stated the use of one symptom or another as indicators for onset of heat in either cows or buffaloes, with distinct differences in the frequency, Bellowing symptom used to detect estrus in buffaloes was $60.67 \%$, while it was $21.47 \%$ and 10.57 in Baladi and cross bred cows, respectively. While mounting as other symptom were $46.17,40.59$ and $4.59 \%$ from total symptoms observation in Baladi and cross bred cows and buffaloes, respectively. On the other hand, response to putting hand on rump, tail raising and response to vulva message were more frequency used to determine heat in cattle and buffaloes after previous symptoms. Such results were similar to those obtained by Barkawi $\boldsymbol{e t}$ al. (1993) and Aboul-Ela et al. (2000). It seems that in small holders do not face much difficulty in detecting estrus in their animals, which are kept close to them and receive much attention by the farmers who are normally familiar with their individual behaviour.

Table 7: The symptoms used for detection of estrus in Baladi, cross breed cows and buffaloes by small farmer expressed as percentage of observations.

\begin{tabular}{|l|c|c|c|}
\hline \multicolumn{1}{|c|}{ Symptom } & Baladi cows & Cross breed cows & buffaloes \\
\hline Bellowing & 21.47 & 10.57 & 60.67 \\
\hline Mounting others & 46.4 & 40.60 & 4.59 \\
\hline Response to vulva message & 5.36 & 6.73 & 10.17 \\
\hline Low appetite & 1.82 & 1.84 & 1.53 \\
\hline Response to putting hand on rump & 11.29 & 17.29 & 9.64 \\
\hline Tail raising & 6.83 & 13.46 & 6.62 \\
\hline High body temperature & 3.83 & 3.73 & 3.11 \\
\hline Drop in milk production & 3.21 & 5.78 & 3.67 \\
\hline
\end{tabular}

Data of reproductive parameters are presented in (Table 8). Age at first calving (AFC) was significantly $(\mathrm{p}<0.05)$ higher in buffaloes than cattle, the same trend was noticed in post-partum service interval (PPSI). Age at first calving is affected by genetic, but it is also correlated with good feeding, management system and climatic conditions. Improvement of feeding system for cattle would result in shortening age at first calving.

Also, species of animal have significant effect $(p<0.05)$ on post-partum estrous interval, (PPEI), which was higher in buffaloes $(92.58 \pm 4.68)$ than either Baladi cows (73.46 \pm 2.94$)$ and crossbreed cows $(80.44 \pm 3.20)$. This result supported that feeding system is related to body state and ovary respectively.

Fayoum J. Agric. Res. \& Dev., Vol. 21, No.1, January, 2007 
THE REPRODUCTIVE PERFORMANCE OF EGYPTIAN COWS AND... I

Table 8: Means + SE of reproductive parameters of Baladi 'cross breed cows and buffaloes maintained at small holdings.

\begin{tabular}{|c|c|c|c|}
\hline parameters & Baladi cows & Cross breed cows & Buffaloes \\
\hline AFC (month ) & $32.42 \pm 1.52^{\mathrm{b}}$ & $33.44 \pm 1.40^{\mathrm{ab}}$ & $34.86 \pm 1.86^{\mathrm{a}}$ \\
\hline PPEL (day) & $73.46 \pm 2.94^{\mathrm{c}}$ & $80.44 \pm 3.20^{\mathrm{b}}$ & $92.58 \pm 4.68^{\mathrm{a}}$ \\
\hline PPSI (day) & $73.92 \pm 2.52^{\mathrm{b}}$ & $83.12 \pm 2.82^{\mathrm{ab}}$ & $91.5 \pm 3.46^{\mathrm{a}}$ \\
\hline NSC (day) & $1.50 \pm 0.12^{\mathrm{b}}$ & $1.58 \pm 0.11$ & $1.68 \pm 0.11$ \\
\hline SP (day) & $41.76 \pm 1.88^{\mathrm{b}}$ & $46.02 \pm 1.94^{\mathrm{a}}$ & $48.2 \pm 2.12^{\mathrm{a}}$ \\
\hline DO (day) & $101.06 \pm 3.08^{\mathrm{b}}$ & $105.04 \pm 3.10^{\mathrm{b}}$ & $119.94 \pm 3.32^{\mathrm{a}}$ \\
\hline GP (day) & $285.88 \pm 1.4^{\mathrm{b}}$ & $289.52 \pm 1.60^{\mathrm{b}}$ & $324.64 \pm 1.6^{\mathrm{a}}$ \\
\hline CI (day ) & $386.94 \pm 13.2^{\mathrm{b}}$ & $396.76 \pm 13.50^{\mathrm{b}}$ & $444.58 \pm 14.74^{\mathrm{a}}$ \\
\hline
\end{tabular}

Means in the same row having different superscripts significantly different $(\mathrm{p}<0.05)$

The same trend was observed in service period (SP), which was significantly higher in buffaloes than both Baladi or crossbreed cows. While, species of animal cattle or buffaloes influenced significantly $(\mathrm{p}<0.05)$, days open (DO) parameters, gestation pried (GP) and calving interval (CI), all parameters were higher in buffaloes followed by cross breed cows and Baladi cows. Variations were observed within species in most of the paramets and could be attributed mainly to the differences in management practices and/or genetic makeup of different animals.

The common idea that, buffaloes are lower than cattle in reproductive performance is supported by the present results under the traditional management system in small farms as found by El-Wardani et al., (2000). Close and individual attention given to each animal in the small holdings lead to such reproductive performance. Nevertheless, the Baladi and crossbreed cows showed better performance than buffaloes raised at small holdings, while may be related to genetic improvements.

\section{REFERENCES}

Aboul-Ela, M.B. 1993. Oestrous detection and reproductive management of buffaloes raised in small holdings in Egypt: A survey study. Proceedings of International Symposium on ' Prospects of buffalo Production No. 62, Pudoc Wageningen, The Netherlands,.381-384

Aboul-Ela, M.B. 1999. Oestrous detection and reproductive management of buffaloes raised in small holdings in Egypt. A survey study. Proceedings of International Symposium on" prospects of buffalo production in the Mediterranean and the Middle East., EAAP Publication No.62, Pudoc Wageningen, the Netherlands, pp.381-384.

Aboul-Ela, M.B., M.A. El-Wardani and H. Almahdy 2000. Characterization of management practices of buffaloes raised under traditional conditions of small holdings. Proc. Conf. Anim. Prod. In The $21^{\text {th }}$ Century, Sakha, $18-20$ April 2000: 335 - 344 .

Barkawi, A.H., Bedier, L. H. and M.A. El-Wardani. 1993. Sexual behavior of Egyption buffaloes in postpartum period. Buffalo J., 9: 225-236.

CID. 2005. Fayoum Governorate Description with Information. Center of Information and Disigan. Egypt. 8 -14.

Corro,M., Rubio,I, Castilla,E., Galindo.,L., Aluja,A., Galina,C.S. and C. Murcia. 1999. Effect of blood metabolites, body condition and pusture management on milk yield and postpartum intervals in dual purpose cattle farms in the tropics of the statc of Vera Cruz, Mexico,Vet. Med., 38: 101-113.

Fayoum J. Agric. Res. \& Dev., Vol. 21, No.1, January, 2007 
El-Kashab, S. M. S. El-Dannasoury and S. Omer. 1984. Studies on some reproductive and productive traits of buffaloes in Egypt. Minufiy J. Agric. Res. 9: 211-237.

El-Wardani, M.A., H. Almahdy, A.S. Tabana and M.k., Hathout, 2000. Reproductive performance of the Baladi cows and buffaloes under traditional management system in Egyption small holdings. Animal production in the $21^{\text {st }}$ Century. Challenges and Prospects. Sakha, Kafr El- Sheikh Egypt, April 18- $20,325-333$.

Hathout, M.K., S.A. El-Saadany, A.S. Tabana, M.M. Ismail and I.M. Gomaa. 1996. Features of dairy farming under group - livestock mixed system in the Delta region, Egypt. Proceedings of International Symposium on Buffalo resources and production systems Cairo, Egypt, 14-16 Oct., 30-40.

Nigm, A.A.1996. Characterization of the Egyption Buffalo proceedings of International symposium on Buffalo resourced and production systems. Cairo Egypt. $14-17$ Oct. pp $1-8$.

Sadek, R.R., A.M. Ahmed and A.S. Abdel. Aziz. 1994. Farm budget of three types of small scale mixed farm under the livestock/crop system in a new land in Egypt. Proceedings of the $3^{\text {rd }}$ International Livestock Farming System Symposium, Aberdeen, Scotland, No. 7.

Salem, F.A. 2003. Effect of dietary silage source on feed intake, nutrients digestibility, some blood constituents and milk production in lactating buffaloes. Egyptian J. Nutrition and feeds (2003) 6: 573 - 586

SPSS. 1997. Statistical Package for Social Science. Release 8-0 Copyright $\odot$, SPSS. INC., Chicago, U.S.A

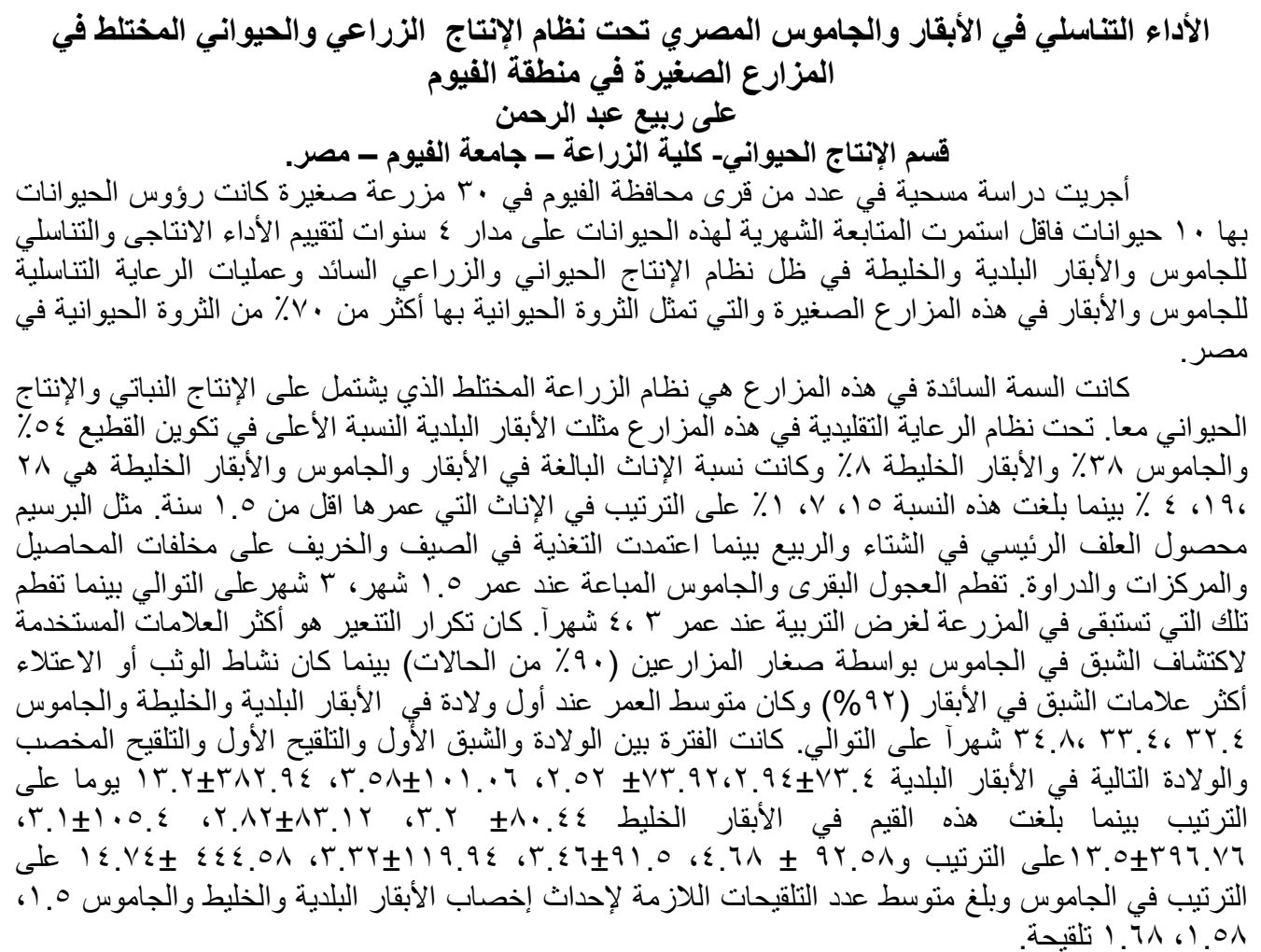

Fayoum J. Agric. Res. \& Dev., Vol. 21, No.1, January, 2007 